\title{
Respon Pertumbuhan Tanaman Cengkeh (Syzygium aromaticum (L.) Merr. Perr.) dengan Aplikasi Pupuk Organik-Anorganik dan Triakontanol
}

\author{
Plant Growth Response of Clove (Syzygium aromaticum (L.) Merr. Perr.) with \\ the Application of Organic-Inorganic Fertilizers and Triacontanol
}

\author{
Syahdin Launuru ${ }^{1}$, Ade Wachjar ${ }^{2 *}$, dan Ani Kurniawati ${ }^{2}$ \\ 'Program Studi Agronomi dan Hortikultura, Sekolah Pascasarjana, Institut Pertanian Bogor \\ ${ }^{2}$ Departemen Agronomi dan Hortikultura, Fakultas Pertanian, Institut Pertanian Bogor \\ (Bogor Agricultural University), Jl. Meranti, Kampus IPB Darmaga, Bogor 16680, Indonesia
}

Diterima 10 Mei 2019/Disetujui 18 November 2019

\begin{abstract}
Application of right dosage of fertilizer and concentration of plant growth regulator are supporting factor of clove growth. This study was aimed to obtain the best combination of organic-inorganic fertilizer, the best triacontanol concentration and both interactions for increasing clove growth. This study used a Randomized Complete Block Design (RCBD) with two factors. The first factor was the organic-inorganic fertilizer dosage package that consisted of 6 levels, i.e no fertilizer, $100 \%$ recommended dosage of inorganic fertilizer (r.d.i.f), $25 \%$ recommended dosage of organic fertilizer (r.d.o.f) $+75 \%$ r.d.i.f, $50 \%$ r.d.o.f $+50 \%$ r.d.i.f, $75 \%$ r.d.o.f $+25 \%$ r.d.i.f, $100 \%$ r.d.o.f. The second factor was the concentration of triacontanol that consisted of 3 levels, i.e no triacontanol, $2 \mathrm{mg} \mathrm{L}^{-1}$ and $4 \mathrm{mg} \mathrm{L}^{-1}$. The results showed that the application of $25 \%$ r.d.o.f + $75 \%$ r.d.i.f produced the best clove growth, but it was not significantly different from the combination treatment of the two other types of fertilizer as indicated by the greatest improvement on stem diameter, branches number, leaf area, chlorophyll $a$, chlorophyll b, total chlorophyll and carotenoids. Clove plants did not respond to the application of triacontanol at a concentration of $2 \mathrm{mg} \mathrm{L}^{-1}$, but gave a negative response to the application of triacontanol $4 \mathrm{mg} \mathrm{L}^{-1}$ on the plant height and leaf area variables. The interaction of the two factors did not have significant effects on all variables.
\end{abstract}

Keywords: chlorophyll, morphology, nutrient dynamics, physiology, vegetative growth

\section{ABSTRAK}

Aplikasi dosis pupuk dan konsentrasi zat pengatur tumbuh yang tepat merupakan faktor pendukung pertumbuhan tanaman cengkeh. Penelitian ini bertujuan untuk mendapatkan kombinasi terbaik dari pupuk organik-anorganik, konsentrasi triakontanol terbaik dan interaksi keduanya untuk meningkatkan pertumbuhan cengkeh. Penelitian ini menggunakan rancangan acak kelompok Lengkap (RAK) dengan dua faktor. Faktor pertama adalah paket dosis pupuk organik-anorganik yang terdiri atas 6 taraf, yaitu tanpa pupuk, 100\% dosis anjuran pupuk anorganik (d.a.p.a), 25\% dosis anjuran pupuk organik (d.a.p.o) $+75 \%$ d.a.p.a, $50 \%$ d.a.p.o $+50 \%$ d.a.p.a, $75 \%$ d.a.p.o $+25 \%$ d.a.p.a, $100 \%$ d.a.p.o. Faktor kedua yaitu konsentrasi triakontanol yang terdiri atas tanpa triakontanol, $2 \mathrm{mg} \mathrm{L^{-1 }}$ dan $4 \mathrm{mg} \mathrm{L}^{-1}$. Hasil penelitian menunjukkan bahwa aplikasi $25 \%$ d.a.p.o $+75 \%$ d.a.p.a menghasilkan pertumbuhan cengkeh terbaik, tetapi tidak berbeda nyata dengan perlakuan kombinasi dosis dua jenis pupuk lainnya yang ditunjukkan oleh peningkatan terbesar pada diameter batang, jumlah cabang, luas daun, klorofil a, klorofil b, total klorofil, dan karotenoid. Tanaman cengkeh tidak memberikan respon terhadap aplikasi triakontanol pada konsentrasi $2 \mathrm{mg} \mathrm{L}^{-1}$, namun memberikan respon negatif terhadap aplikasi triakontanol $4 \mathrm{mg} \mathrm{L}^{-1}$ pada peubah tinggi tanaman dan luas daun. Interaksi kedua faktor tidak memberikan pengaruh nyata terhadap sетиа peubah.

Kata kunci: dinamika hara, fisiologi, klorofil, morfologi, pertumbuhan vegetatif

* Penulis untuk korespondensi. e-mail: wachjarade@yahoo.co.id 


\section{PENDAHULUAN}

Produksi cengkeh di Indonesia dalam kurun waktu 2011-2017 mengalami peningkatan setiap tahun. Peningkatan produksi cengkeh karena adanya pertambahan luas areal tanaman cengkeh, baik perkebunan rakyat, negara, maupun swasta. Luas areal tanaman cengkeh di Indonesia pada tahun 2011 adalah 485,191 ha dengan produksi cengkeh sebesar 72,207 ton, meningkat menjadi 548,091 ha dengan produksi cengkeh sebesar 123,773 ton pada tahun 2017. Produktivitas tanaman cengkeh dari tahun 2011-2017 berkisar 238-381 $\mathrm{kg} \mathrm{ha}^{-1}$. Produktivitas tanaman cengkeh tersebut masih di bawah potensinya, yaitu sebesar 500-600 $\mathrm{kg} \mathrm{ha}^{-1}$ (Ditjenbun, 2017). Tanaman cengkeh yang berada di sentra produksi cengkeh umumnya dibudidayakan pada tanah-tanah yang memiliki tingkat kesuburan rendah dan sifat fisik yang beragam (Setiawan dan Rosman, 2015).

Pemupukan merupakan salah satu upaya untuk meningkatkan kesuburan tanah dan pertumbuhan tanaman. Pemberian pupuk organik dapat meningkatkan $\mathrm{pH}$ tanah, kapasitas air, kapasitas tukar kation (KTK), porositas, serta merangsang pertumbuhan mikroorganisme di dalam tanah (Leszczynska dan Malina, 2011). Aplikasi pupuk organik dapat meningkatkan kandungan hara $\mathrm{N}$ dan $\mathrm{P}$ pada daun tanaman kelapa sawit lebih tinggi dibanding tanpa pemberian pupuk organik (Kanny, 2015) dan meningkatkan kandungan hara $\mathrm{K}$ daun serta total serapan hara $\mathrm{K}$ dan $\mathrm{N}$ pada tanaman kedelai (Sudarsono et al., 2013). Veras et al. (2016) menyatakan bahwa pemberian pupuk kandang pada tanaman jambu biji dapat meningkatkan tinggi tanaman, diameter batang, jumlah daun, luas daun, dan panjang akar jika dibandingkan tanpa pupuk kandang.

Nitrogen berperan dalam memacu pertumbuhan vegetatif tanaman karena adanya peningkatan laju fotosintesis akibat bertambahnya pembetukan klorofil daun (Shintarika et al., 2015). Fosfor berperan dalam proses penangkapan energi cahaya matahari dan mengubahnya menjadi energi biokimia. Kalium merupakan unsur penting dalam proses fisiologis seperti pengendalian tekanan osmotik, turgor sel, stabilitas $\mathrm{pH}$, dan pengaturan air melalui kontrol stomata, aktivasi berbagai macam enzim dan translokasi fotosintat (Oosterhuis et al., 2014). Selain itu, untuk merangsang pertumbuhan tanaman dapat juga menggunakan zat pengatur tumbuh antara lain triakontanol.

Triakontanol merupakan salah satu zat pengatur tumbuh dan termasuk turunan alkohol alifatik yang berantai panjang dengan rumus molekul $\mathrm{CH}_{3}\left(\mathrm{CH}_{2}\right)_{28} \mathrm{CH}_{2} \mathrm{OH}$ (Ries, 1985).Aplikasitriakontanoldapatmeningkatkankonduktansi stomata, laju transpirasi, laju fotosintesis, penyerapan air dan nutrisi serta peningkatan aktivitas metabolisme tanaman (Krishnan dan Kumari, 2008). Lebih lanjut Sharma dan Joolka (2000) menjelaskan bahwa pemberian triakontanol pada tanaman almond dapat meningkatkan konduktansi stomata, laju transpirasi, kandungan klorofil daun dan laju fotosintesis. Peningkatan respon fisiologi merupakan indikator meningkatnya pertumbuhan tanaman. Pemberian triakontanol dapat meningkatkan kandungan hara $\mathrm{N}, \mathrm{P}$ dan $\mathrm{K}$ daun pada tanaman almond (Sharma dan Joolka, 2011), meningkatkan tinggi tanaman, ketebalan batang, volume pohon dan mempercepat pertumbuhan tunas pada tanaman kenari (Tomar dan Singh, 2007), meningkatkan jumlah akar tanaman kayu (Tantos et al., 2001). Oleh sebab itu, pemberian triakontanol diharapkan dapat merangsang proses fisiologi tanaman cengkeh pada kondisi lingkungan suboptimal. Tujuan penelitian ini adalah untuk mendapatkan paket pupuk organik-anorganik dan konsentrasi triakontanol yang terbaik untuk meningkatkan pertumbuhan tanaman cengkeh.

\section{BAHAN DAN METODE}

Penelitian ini dilaksanakan pada bulan Oktober 2017 sampai dengan April 2018 di Kebun Percobaan Cikabayan, Institut Pertanian Bogor, Dramaga, Bogor, Jawa Barat. Lokasi penelitian terletak pada ketinggian 240 meter di atas permukaan laut dengan jenis tanah Latosol. Bahan yang digunakan adalah tanaman cengkeh tipe Zanzibar yang telah berumur lima tahun yang ditanam dengan jarak tanam $8 \mathrm{~m} \mathrm{x} 4 \mathrm{~m}$. Selain itu, digunakan juga pupuk organik yang berasal dari pupuk kandang sapi, pupuk anorganik berupa Urea $(45 \% \mathrm{~N})$, SP-36 $\left(36 \% \mathrm{P}_{2} \mathrm{O}_{5}\right), \mathrm{KCl}\left(60 \% \mathrm{~K}_{2} \mathrm{O}\right)$. Untuk sumber triakontanol digunakan zat pengatur tumbuh (ZPT) Hobsanol 5 EC.

Rancangan percobaan yang digunakan adalah rancangan acak kelompok (RAK) yang disusun secara faktorial dengan dua faktor perlakuan. Faktor perlakuan pertama yaitu paket dosis pupuk organik-anorganik yang terdiri atas tanpa pupuk, $100 \%$ dosis anjuran pupuk anorganik (d.a.p.a), $25 \%$ dosis anjuran pupuk organik (d.a.p.o) $+75 \%$ d.a.p.a, $50 \%$ d.a.p.o $+50 \%$ d.a.p.a, $75 \%$ d.a.p.o $+25 \%$ d.a.p.a, $100 \%$ d.a.p.o. Dosis anjuran pupuk organik dan anorganik dapat dilihat pada Tabel 1. Faktor kedua yaitu konsentrasi triakontanol yang terdiri atas tanpa triakontanol, $2 \mathrm{mg} \mathrm{L}^{-1}$ dan $4 \mathrm{mg} \mathrm{L}^{-1}$. Dengan demikian, terdapat 18 kombinasi perlakuan dan setiap kombinasi perlakuan diulang lima kali, sehingga terdapat 90 satuan percobaan. Masing-masing satuan percobaan digunakan satu tanaman, sehingga dibutuhkan 90 tanaman cengkeh.

Perlakuan pupuk organik diaplikasikan sebanyak satu kali pada awal percobaan. Dosis pupuk organik dapat dilihat pada Tabel 1. Aplikasi pupuk anorganik dilakukan dua kali, yaitu pada awal percobaan dan dua bulan kemudian dengan masing-masing setengah dosis perlakuan (Tabel 1). Menurut Puslitbangbun (2007) bahwa anjuran dosis pupuk anorganik untuk tanaman cengkeh umur lima tahun yaitu Urea $0.6 \mathrm{~kg}$ per tanaman per tahun, SP-36 $0.4 \mathrm{~kg}$ per tanaman per tahun dan $\mathrm{KCl} 0.4 \mathrm{~kg}$ per tanaman per tahun. Aplikasi triakontanol dilakukan sebanyak enam kali. Aplikasi pertama dilakukan satu minggu setelah pemupukan pertama dengan interval waktu aplikasi sebulan sekali selama enam bulan. Aplikasi triakontanol dilakukan dengan cara penyemprotan secara merata ke seluruh permukaan daun (tajuk) tanaman cengkeh dengan volume semprot $1 \mathrm{~L}$ per tanaman dan sesuai konsentrasi perlakuan. Aplikasi triakontanol dilakukan pada siang hari karena menurut Ries dan Houtz (1983) bahwa suhu tinggi sangat berperan terhadap aktivitas triakontanol sehingga aplikasi terbaik yaitu pada siang hari.

Pengamatan tinggi tanaman, diameter batang dan jumlah cabang primer dilakukan sebelum perlakuan dan 
Tabel 1. Perlakuan pupuk organik-anorganik pada tanaman cengkeh

\begin{tabular}{lcccccc}
\hline \multicolumn{2}{c}{ Persentase dosis pupuk } & & \multicolumn{4}{c}{ Dosis pupuk yang digunakan } \\
\cline { 1 - 2 } \cline { 5 - 6 } $\begin{array}{l}\text { Organik } \\
(\%)\end{array}$ & $\begin{array}{c}\text { Anorganik } \\
(\%)\end{array}$ & & $\begin{array}{c}\text { Organik (kg per tanaman } \\
\text { per 6 bulan) }\end{array}$ & & \multicolumn{2}{c}{ Anorganik (kg per tanaman per 6 bulan) } \\
\cline { 5 - 7 } & 100 & 0 & 0.60 & Urea & 0.4 & 0.4 \\
25 & 75 & 5 & 0.45 & 0.3 & 0.3 \\
50 & 50 & 10 & 0.30 & 0.2 & 0.2 \\
75 & 25 & 15 & 0.15 & 0.1 & 0.1 \\
100 & 0 & 20 & 0.00 & 0.0 & 0.0 \\
\hline
\end{tabular}

mulai umur dua minggu setelah perlakuan pemupukan dengan interval waktu pengamatan dua minggu sekali hingga akhir percobaan (6 bulan). Pengamatan luas daun, klorofil a, klorofil b, karotenoid, total klorofil dan dinamika hara dilakukan pada akhir percobaan. Pengukuran luas daun diambil satu helai daun pada posisi daun ke-5 dari cabang sehat yang mewakili bagian atas tajuk, bagian tengah tajuk dan bagian bawah tajuk. Indeks luas daun diamati pada daun sehat, dewasa dan terbuka sempurna.

Data luas daun, klorofil a, klorofil b, karotenoid, total klorofil dan dinamika hara dianalisis menggunakan sidik ragam, sedangkan data tinggi tanaman, diameter batang dan jumlah cabang dianalisis menggunakan sidik peragam karena ketidakseragaman sampel tanaman sehingga data awal (data sebelum perlakuan) dijadikan sebagai kovariat untuk masing-masing peubah. Apabila perlakuan berpengaruh nyata terhadap respon yang diamati, analisis data dilanjutkan dengan uji Duncan Multiple Range Test (DMRT) pada taraf $5 \%$ untuk sidik ragam dan uji lanjut Beda Nyata Jujur (BNJ) pada taraf $5 \%$ untuk sidik peragam.

\section{HASIL DAN PEMBAHASAN}

Hasil analisis tanah awal dapat memberikan gambaran umum terkait sifat fisik dan kimia tanah pada lahan percobaan. Sifat fisik berupa tekstur tanah pada lahan percobaan terdiri atas fraksi pasir $6.61 \%$, debu $15.36 \%$ dan liat $78.03 \%$. Hal ini menggambarkan bahwa tekstur tanah pada lahan percobaan tergolong liat. Hasil analisis tanah awal di lokasi lahan percobaan berupa sifat kimia tanah dan disesuaikan berdasarkan kriteria Balittanah (2009) menunjukkan bahwa tanah di lahan percobaan tergolong sangat masam dengan nilai $\mathrm{pH}\left(\mathrm{H}_{2} \mathrm{O}\right) 4.22$ sehingga dapat berpengaruh negatif terhadap kandungan hara di dalam tanah. Kandungan hara tanah pada lahan percobaan memperlihatkan bahwa C-organik rendah, N-total sedang, $\mathrm{P}$ rendah, $\mathrm{K}$ rendah, Ca sangat rendah, $\mathrm{Mg}$ rendah, kapasitas tukar kation (KTK) sedang dan kejenuhan basa (KB) sangat rendah. Choudhury dan Sharma (2014) menjelaskan bahwa $\mathrm{pH}$ rendah mengakibatkan ketersediaan hara $\mathrm{N}, \mathrm{P}, \mathrm{K}, \mathrm{Ca}$, $\mathrm{Mg}$ dan Mo menjadi kurang tersedia bagi tanaman dan kelarutan aluminium (Al) menjadi $\mathrm{Al}^{3+}$ semakin meningkat sehingga sangat toksik bagi tanaman.

\section{Hasil Sidik Ragam dan Peragam}

Hasil sidik ragam dan peragam menujukkan bahwa aplikasi pupuk organik-anorganik berpengaruh nyata terhadap diameter batang, jumlah cabang, luas daun, klorofil b, klorofil a, total klorofil, dan karotenoid akan tetapi tidak berpengaruh nyata terhadap tinggi tanaman. Aplikasi triakontanol hanya memberikan pengaruh nyata pada peubah tinggi tanaman dan luas daun. Interaksi antara pupuk organik-anorganik dan triakontanol tidak memberikan pengaruh nyata.

\section{Pupuk Organik-Anorganik}

Hasil sidik ragam dan peragam menujukkan bahwa aplikasi pupuk organik-anorganik berpengaruh nyata terhadap diameter batang, jumlah cabang, luas daun, klorofil a, klorofil b, total klorofil dan karotenoid. Aplikasi 25\% d.a.p.o $+75 \%$ d.a.p.a dapat meningkatan diameter batang, jumlah cabang primer dan luas daun pada 24 minggu setelah perlakuan pertama (MSPP) berturut-turut sebesar 10.05\%, $21.05 \% 46.05 \%$ dibandingkan kontrol serta $10.47 \%$, $43.75 \%$ dan $51.57 \%$ dibandingkan aplikasi $100 \%$ d.a.p.a (Tabel 2). Peningkatan persentase pertumbuhan tanaman cengkeh disebabkan adanya kombinasi perlakuan pupuk organik dan anorganik. Hasil penelitian Oyewole et al. (2012) menyimpulkan bahwa peningkatan diameter batang tanaman kakao yang lebih besar terdapat pada aplikasi kombinasi pupuk organik-anorganik secara bersama-sama bila dibandingkan dengan perlakuan pupuk organik atau anorganik secara terpisah. Aplikasi pupuk organik dapat memperbaiki sifat fisik tanah sehingga tanah mampu menyimpan dan menyediakan air (Scotti et al., 2013) serta meningkatkan pertumbuhan akar dan penyerapan hara bagi tanaman (Triadiati et al., 2013). Hal ini dibuktikan dengan adanya peningkatan kandungan hara $\mathrm{N}$ pada daun tanaman kelapa sawit yang diberi pupuk organik (Kanny, 2015). Akumulasi hara $\mathrm{N}$ di daun akan dimanfaatkan untuk proses fisiologi dan biokimia karena nitrogen memiliki peran dalam pembentukan klorofil. Peningkatan kandungan klorofil di daun diduga menyebabkan aktivitas fotosintesis meningkat sehingga asimilat yang dihasilkan lebih banyak dan ditranslokasikan pada bagian tanaman untuk pertumbuhan dan perkembangan tanaman cengkeh. 
Hasil penelitian menunjukkan bahwa aplikasi $25 \%$ d.a.p.o $+75 \%$ d.a.p.a dan $50 \%$ d.a.p.o $+50 \%$ d.a.p.a dapat meningkatkan kandungan klorofil a, klorofil b, karotenoid dan total klorofil pada daun tanaman cengkeh (Tabel 3). Hasil ini sejalan dengan penelitian Muliasari et al. (2016) bahwa penggunaan pupuk organik-anorganik mampu menghasilkan kandungan klorofil a, klorofil b dan total klorofil tanaman kopi lebih baik. Hal ini dikarekan adanya peran pupuk organik yang mampu menahan air dan menjerap unsur hara dengan baik sehingga pupuk anorganik yang diberikan mudah diserap oleh tanaman cengkeh. Pupuk anorganik berupa pupuk tunggal nitrogen yang dikombinasikan dengan pupuk organik dalam penelitian ini merupakan faktor penting dalam pembentukan klorofil. Menurut Sudradjat et al. (2015) bahwa peningkatan kandungan klorofil pada tanamam kelapa sawit sangat dipengaruhi oleh ketersediaan nitrogen. Lebih lanjut Purwanto et al. (2017) menyatakan bahwa tingkat kehijauan daun yang tinggi berkorelasi dengan banyaknya kandungan klorofil merupakan salah satu indikator peningkatan pertumbuhan dan produksi tanaman sawit.

\section{Triakontanol}

Aplikasi triakontanol memberikan pengaruh nyata terhadap tinggi tanaman dan luas daun, tetapi tidak memberikan pengaruh nyata terhadap diameter batang, jumlah cabang, klorofil a, klorofil b, karotenoid dan total klorofil (Tabel 2 dan 3). Pemberian triakontanol dengan konsentrasi tinggi dapat menghambat peningkatan tinggi tanaman. Hasil penelitian menunjukkan bahwa semakin tinggi konsentrasi triakontanol hingga $4 \mathrm{mg} \mathrm{L}^{-1}$ dapat menghambat tinggi tanaman cengkeh pada 24 MSPP (Tabel 2). Terhambatnya pertumbuhan tanaman disebabkan oleh konsentrasi triakontanol yang lebih tinggi (Hoagland, 1980; Ries dan Houtz, 1983; Naeem et al., 2009). Hal ini dikarenakan adanya peran triakontanol yang dapat meningkatkan konduktansi stomata (Aftab et al., 2010) sehingga laju transpirasi semakin meningkat yang menyebabkan kehilangan air dari jaringan tanaman lebih tinggi. Oleh karena itu, tanaman mengalami defisit air sehingga pertumbuhan tanaman terhambat.

Budisantoso et al. (2004) menyimpulkan bahwa aplikasi konsentrasi triakontanol hingga 4 ppm pada tanaman tempuyung masih meningkatkan laju pertumbuhan relatif dan bobot kering secara optimal, sedangkan konsentrasi triakontanol di atas 4 ppm menyebabkan penurunan hasil dan menghambat pertumbuhan tanaman tempuyung. Menurut Sitinjak dan Pandiangan (2014) bahwa pemberian triakontanol melalui daun dengan konsentrasi $1.0 \mathrm{ml} \mathrm{L}^{-1}$ dapat meningkatkan pertumbuhan bibit kakao jauh lebih baik daripada konsentrasi $2.0 \mathrm{ml} \mathrm{L}^{-1}$. Hal ini menunjukkan bahwa respon tanaman berbeda-beda terhadap konsentrasi triakontanol.

Semakin tinggi konsentrasi triakontanol yang diaplikasikan dapat menurunkan luas daun (Tabel 2). Zat pengatur tumbuh aktif pada konsentrasi rendah dan beracun pada konsentrasi tinggi (Wattimena, 1988). Zat pengatur tumbuh dapat mempengaruhi lintasan tranduksi sinyal pada sel target sehingga berpengaruh terhadap metabolisme dan pertumbuhan sel-sel tanaman. Respon seluler yang dipengaruhi oleh zat pengatur tumbuh menyebabkan adanya ekspresi gen, menghambat atau mengaktivasi enzim serta mengubah komposisi membran di dalam jaringan tanaman (Garuda, 2015). Luas daun sangat mempengaruhi proses penangkapan energi cahaya matahari. Oleh sebab itu, peningkatan luas daun dapat meningkatkan penangkapan energi cahaya matahari yang

Tabel 2. Respon tinggi tanaman, diameter batang, dan jumlah cabang terhadap berbagai dosis pupuk organik-anorganik dan konsentrasi triakontanol pada 24 MSPP

\begin{tabular}{lcccc}
\hline & \multicolumn{3}{c}{ Peubah } \\
\cline { 2 - 5 } Perlakuan & $\begin{array}{c}\text { Tinggi tanaman } \\
(\mathrm{cm})\end{array}$ & $\begin{array}{c}\text { Diameter batang } \\
(\mathrm{mm})\end{array}$ & $\begin{array}{c}\text { Jumlah cabang } \\
(\text { cabang })\end{array}$ & $\begin{array}{c}\text { Luas daun } \\
\left(\mathrm{cm}^{2}\right)\end{array}$ \\
\hline Dosis pupuk & 169.11 & $18.31 \mathrm{~b}$ & $18.60 \mathrm{ab}$ & $16.46 \mathrm{bc}$ \\
0 (kontrol) & 166.51 & $18.24 \mathrm{~b}$ & $16.12 \mathrm{~b}$ & $15.86 \mathrm{bc}$ \\
$0 \%$ d.a.p.o $+100 \%$ d.a.p.a & 171.46 & $20.15 \mathrm{a}$ & $22.64 \mathrm{a}$ & $24.04 \mathrm{a}$ \\
25\% d.a.p.o $+75 \%$ d.a.p.a & 176.28 & $18.80 \mathrm{ab}$ & $20.96 \mathrm{ab}$ & $20.40 \mathrm{ab}$ \\
$50 \%$ d.a.p.o $+50 \%$ d.a.p.a & 170.68 & $19.17 \mathrm{ab}$ & $20.65 \mathrm{ab}$ & $18.63 \mathrm{abc}$ \\
$75 \%$ d.a.p.o $+25 \%$ d.a.p.a & 166.74 & $18.79 \mathrm{ab}$ & $20.76 \mathrm{ab}$ & $13.87 \mathrm{c}$ \\
$100 \%$ d.a.p.o $+0 \%$ d.a.p.a & & & 19.91 & $18.43 \mathrm{ab}$ \\
Triakontanol $(\mathrm{mg}$ L-1) & $175.05 \mathrm{a}$ & 19.27 & 20.74 & $19.82 \mathrm{a}$ \\
0 & $168.81 \mathrm{ab}$ & 18.87 & 18.59 & $16.14 \mathrm{~b}$ \\
\hline
\end{tabular}

Keterangan: Angka-angka yang diikuti huruf yang sama pada kolom dan perlakuan yang sama tidak berpengaruh nyata pada uji BNJ (tinggi tanaman, diameter batang, jumlah cabang) dan DMRT (luas daun) taraf $\alpha 5 \%$; MSPP = minggu setelah perlakuan pertama; d.a.p.o $=$ dosis anjuran pupuk organik; d.a.p.a $=$ dosis anjuran pupuk anorganik 
Tabel 3. Respon klorofil a, klorofil b, total klorofil dan karotenoid terhadap berbagai dosis pupuk organik-anorganik dan triakontanol pada 24 MSPP

\begin{tabular}{|c|c|c|c|c|}
\hline \multirow[b]{2}{*}{ Perlakuan } & \multicolumn{4}{|c|}{ Peubah } \\
\hline & $\begin{array}{c}\text { Klorofil a } \\
\left(\mathrm{mg} \mathrm{g}^{-1}\right)\end{array}$ & $\begin{array}{c}\text { Klorofil b } \\
\left(\mathrm{mg} \mathrm{g}^{-1}\right)\end{array}$ & $\begin{array}{l}\text { Total klorofil } \\
\left(\mathrm{mg} \mathrm{g}^{-1}\right)\end{array}$ & $\begin{array}{c}\text { Karotenoid } \\
\left(\mathrm{mg} \mathrm{g}^{-1}\right)\end{array}$ \\
\hline \multicolumn{5}{|l|}{ Dosis pupuk } \\
\hline 0 (kontrol) & $0.76 \mathrm{~b}$ & $0.30 \mathrm{~b}$ & $1.05 \mathrm{~b}$ & $0.28 \mathrm{~b}$ \\
\hline $0 \%$ d.a.p.o $+100 \%$ d.a.p.a & $0.88 \mathrm{ab}$ & $0.34 \mathrm{ab}$ & $1.21 \mathrm{ab}$ & $0.34 \mathrm{ab}$ \\
\hline $25 \%$ d.a.p.o $+75 \%$ d.a.p.a & $0.97 \mathrm{a}$ & $0.37 \mathrm{a}$ & $1.34 \mathrm{a}$ & $0.35 \mathrm{a}$ \\
\hline $50 \%$ d.a.p.o $+50 \%$ d.a.p.a & $1.02 \mathrm{a}$ & $0.39 \mathrm{a}$ & $1.41 \mathrm{a}$ & $0.36 \mathrm{a}$ \\
\hline $75 \%$ d.a.p.o $+25 \%$ d.a.p.a & $0.92 \mathrm{ab}$ & $0.35 \mathrm{ab}$ & $1.27 \mathrm{ab}$ & $0.34 \mathrm{ab}$ \\
\hline $100 \%$ d.a.p.o $+0 \%$ d.a.p.a & $0.75 b$ & $0.29 b$ & $1.04 \mathrm{~b}$ & $0.29 b$ \\
\hline \multicolumn{5}{|l|}{ Triakontanol $\left(\mathrm{mg} \mathrm{L}^{-1}\right)$} \\
\hline 0 & 0.81 & 0.32 & 1.13 & 0.31 \\
\hline 2 & 0.89 & 0.34 & 1.23 & 0.33 \\
\hline 4 & 0.94 & 0.36 & 1.30 & 0.34 \\
\hline
\end{tabular}

Keterangan: Angka-angka yang diikuti huruf yang sama pada kolom dan peubah yang sama tidak berpengaruh nyata DMRT taraf $\alpha$ 5\%; MSPP = minggu setelah perlakuan pertama; d.a.p.o = dosis anjuran pupuk organik; d.a.p.a $=$ dosis anjuran pupuk anorganik

digunakan dalam proses fotosintesis sehingga akumulasi fotosintat yang dihasilkan juga meningkat. Fotosintat yang dihasilkan akan ditranslokasikan ke bagian tanaman untuk proses pertumbuhan dan perkembangan tanaman (Sudradjat et al., 2015).

\section{Dinamika Hara}

Pengamatan dinamika hara dilakukan pada perlakuan kontrol (tanpa perlakuan pupuk dan triakontanol) dan perlakuan $25 \%$ d.a.p.o $+75 \%$ d.a.p.a dan konsentrasi triakontanol $2 \mathrm{mg} \mathrm{L}^{-1}$ pada akhir penelitian. Pengamatan dinamika hara dilakukan untuk mempelajari dinamika pergerakan hara N-total, P-total dan K-total.

Kandungan N-total pada perlakuan $25 \%$ d.a.p.o $+75 \%$ d.a.p.a dan konsentrasi triakontanol $2 \mathrm{mg} \mathrm{L}^{-1}$ menunjukkan bahwa kandungan $\mathrm{N}$-total terakumulasi lebih banyak pada kedalaman tanah 0-20 cm. Kandungan N-total semakin menurun disertai dengan bertambahya kedalaman tanah. Mobilitas hara $\mathrm{N}$ terjadi sampai pada kedalaman 20-40 cm dan terlihat lambat di kedalaman 40-60 cm (Gambar 1). Hal ini diduga karena peran dari pupuk organik yang mampu menjerap hara sehingga hara terlihat lebih banyak pada lapisan 0-20 cm dan tidak mudah hilang atau tercuci. Sejalan dengan penelitian Havlin et al. (2005) menjelaskan bahwa nitrogen mudah hilang atau tercuci karena nitrogen tidak terjerap oleh kompleks jerapan tanah dan bersifat larut dalam bentuk $\mathrm{NO}_{3}$ Selanjutnya Maathuis (2009) menjelaskan bahwa penyerapan ion $\mathrm{NO}_{3}^{-}$dan $\mathrm{NH}_{4}^{+}$dan asam amino dipengaruhi oleh kondisi $\mathrm{pH}$ tanah dan adaptasi tanaman. Pada $\mathrm{pH}$ tanah rendah tanaman cenderung menyerap $\mathrm{NH}_{4}^{+}$ dan asam amino, sedangkan dalam kondisi $\mathrm{pH}$ tanah lebih tinggi, tanaman lebih menyerap $\mathrm{NO}_{3}^{-}$.

Aplikasi 25\% d.a.p.o $+75 \%$ d.a.p.a dan konsentrasi triakontanol $2 \mathrm{mg} \mathrm{L}^{-1}$ memiliki kandungan P-total pada kedalaman tanah 0-20 $\mathrm{cm}$ dan 40-60 $\mathrm{cm}$ lebih rendah daripada kontrol (Gambar 1). Hasil analisis tanah pada lahan percobaan memperlihatkan bahwa lahan percobaan memiliki $\mathrm{pH}$ tanah sangat masam dan tanah tergolong liat. Kemasaman tanah yang tinggi diduga mengakibatkan terjadinya kelarutan almunium $(\mathrm{Al})$ dari $\mathrm{Al}(\mathrm{OH})^{2+}$ menjadi $\mathrm{Al}^{3+}$ sehingga dapat mengkelat $\mathrm{P}$ dan sangat toksik bagi tanaman. Pengkelatan alumunium terhadap P menyebabkan ketersediaan $\mathrm{P}$ untuk tanaman cengkeh menjadi rendah dan P yang dikelat lebih banyak terakumulasi di sekitar perakaran tanaman cengkeh. Choudhury dan Sharma (2014) menjelaskan bahwa ketersediaan P menjadi kurang tersedia bagi tanaman disebabkan adanya kelarutan alumunium yang dapat mengkelat $\mathrm{P}$ dan membentuk senyawa Al-P. Penggunaan pupuk organik bersumber dari kotoran sapi diduga mampu meningkatkan $\mathrm{pH}$ tanah dan daya simpan air. Peningkatan $\mathrm{pH}$ tanah akan disertai dengan menurunnya kelarutan alumunium sehingga $\mathrm{P}$ yang dikelat alumunium dapat terlepas dan tersedia bagi tanaman.

Kandungan hara K-total di tiga lapisan tanah pada aplikasi $25 \%$ d.a.p.o $+75 \%$ d.a.p.a dan konsentrasi triakontanol $2 \mathrm{mg} \mathrm{L}^{-1}$ secara statistik relatif sama, tetapi kandungan K-total terlihat lebih banyak pada kedalaman 0-20 cm dan menurun pada kedalaman 20-40 cm sampai 40$60 \mathrm{~cm}$ (Gambar 1). Hal ini diduga penggunaan pupuk organik mampu memperbaiki porositas tanah dan daya simpan air sehingga pupuk anorganik yang diberikan mudah larut dan masuk ke kedalaman tanah 20-40 cm hingga ke kedalaman 40-60 cm melalui proses infiltrasi. Havlin et al. (2005) menjelaskan bahwa tanah yang memiliki kandungan liat tinggi mengakibatkan pergerakan $\mathrm{K}$ di dalam tanah menjadi lambat disebabkan ion $\mathrm{K}$ terjerap pada lapisan mineral liat. Choudhury dan Sharma (2014) menyatakan ketersedian $\mathrm{K}$ menjadi kurang tersedia bagi tanaman dikarenakan $\mathrm{pH}$ tanah yang rendah. 
Kandungan N-total (\%)

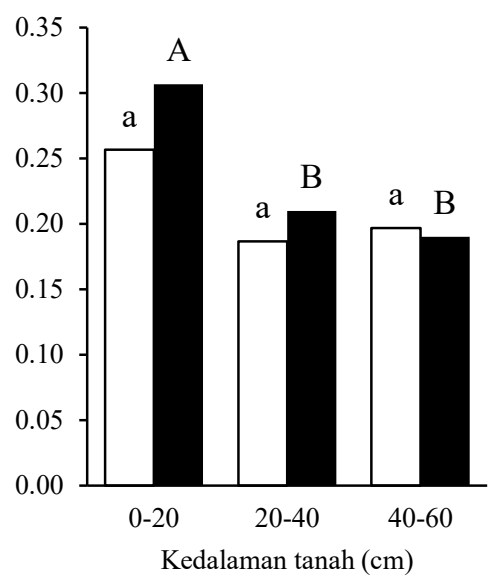

$\square$ Kontrol
Kandungan P-total (mg $\left.100 \mathrm{~g}^{-1}\right)$

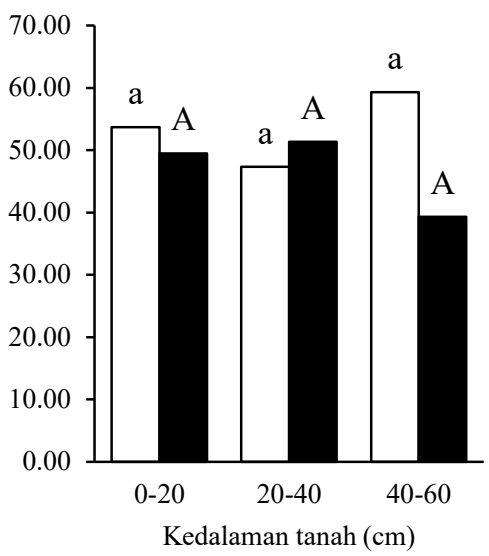

$25 \%$ d.a.p.o $+75 \%$ d.a.p.a dan konsentrasi triakontanol $2 \mathrm{mg} \mathrm{L}^{-1}$
Kandungan K-total (mg $\left.100 \mathrm{~g}^{-1}\right)$

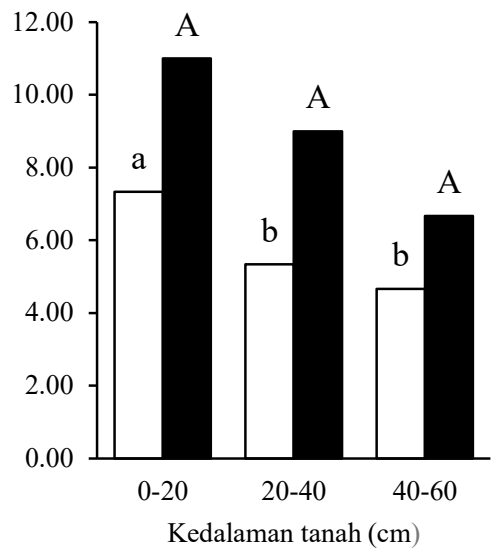

Kedalaman tanah $(\mathrm{cm})$

Gambar 1. Kandungan N-total, P-total dan K-total di dalam tanah pada kedalaman tanah 0-20, 20-40, dan 40-60 cm pada piringan tanaman cengkeh. Angka-angka yang diikuti huruf kecil dan huruf kapital yang sama pada perlakuan yang sama tidak berpengaruh nyata pada uji DMRT taraf $\alpha$ 5\%; d.a.p.o = dosis anjuran pupuk organik; d.a.p.a $=$ dosis anjuran pupuk anorganik

\section{KESIMPULAN}

Kombinasi pupuk 25\% d.a.p.o $+75 \%$ d.a.p.a menghasilkan pertumbuhan cengkeh dan respon fisiologi lebih baik dibandingkan dengan tanpa pupuk. Aplikasi triakontanol $2 \mathrm{mg} \mathrm{L}^{-1}$ tidak memberikan dampak yang berbeda dengan tanpa pemberian triakontanol. Semakin tinggi konsentrasi triakontanol hingga $4 \mathrm{mg} \mathrm{L}^{-1}$ dapat menghambat tinggi tanaman cengkeh.

\section{DAFTAR PUSTAKA}

Aftab, T., M.M.A. Khan, M. Idrees, M. Naeem, M. Singh, M. Ram. 2010. Stimulation of crop productivity, photosynthesis and artemisinin production in Artemisia anпua L. by triacontanol and gibberellic acid application. J. Plant Interactions 5:273-281.

[Balittanah] Balai Penelitian Tanah. 2009. Analisis Kimia Tanah, Tanaman, Air, dan Pupuk. Publ. Balai Penelitian Tanah, Bogor, ID.

Budisantoso, I., S. Wigati, M. Dwiati. 2004. Budidaya tempuyung (Sonchus arvensis L) melalui penyemprotan triakontanol dan pemupukan nitrogen. J. Pembangunan Pedesaan 4:1411-9250.

Choudhury, S., P. Sharma. 2014. Aluminum stress inhibits root growth andalters physiological and metabolic responses in chickpea (Cicer arietinum L.). Plant Physiol. Biochem. 85:63-70.
[Ditjenbun] Direktorat Jenderal Perkebunan. 2017. Statistik Perkebunan Indonesia 2016-2018: Cengkeh. Publ. Kementerian Pertanian, Jakarta, ID.

Garuda. 2015. Peningkatan pertumbuhan dan hasil jagung dengan pemberian pupuk hayati berbasis bakteri pemacu pertumbuhan pada tanah asam. Tesis. Sekolah Pascasarjana. Institut Pertanian Bogor. Bogor.

Havlin, J.L., J.D. Beaton, S.L. Tisdale, W.L. Nelson. 2005. Soil Fertility and Fertilizer. Publ. Pearson Prentice Hall, New Jersey, US.

Hoagland, R.E. 1980. Effect of triacontanol on seed gremination and early growth. Bot. Gaz. 14:53-55.

Kanny, P.I. 2015. Peranan pupuk organik dan anorganik terhadap pertumbuhan kelapa sawit (Elaeis guineensis Jacq.) belum menghasilkan umur dua tahun. Tesis. Sekolah Pascasarjana. Institut Pertanian Bogor. Bogor.

Krishnan, R.R., B.D.R. Kumari. 2008. Effect of Ntriacontanol on the growth of salt stressed soybean plants. J. Biosci. 19:53-62.

Leszczynska, D., J.K. Malina. 2011. Effect of organic matter from various sources on yiled and quality of plant on soils contaminated with heavy metals. J. Ecol Chem. Engin. 18:501-507. 
Maathuis, F. 2009. Physiological functions of mineral nutrients. Curr. Opinion in Plant Biol. 12:250-258.

Muliasari, A.A., A. Wachjar, Supijatno. 2016. Uji Orthogonal kombinasi pupuk anorganik-organik pada pertumbuhan bibit kopi arabika (Coffea arabica L.). Dalam M.R. Suhartanto, M. Syukur, M. Surahman, S. Ilyas, A. Junaedi, A. Kurniawati, S. Marwiyah, H. Furqoni, F.A. Refra. (Eds.). Prosiding Seminar Nasional dan Kongres Perhimpunan Agronomi Indonesia. Bogor 27 April 2016.

Naeem, M., M.M.A. Khan, S.M.H. Moinuddin. 2009. Triacontanol stimulates nitrogen-fixation, enzyme activities, photosynthesis, crop productivity and quality of hyacinth bean (Lablab purpureus L.). Sci. Hortic. 121:389-396.

Oosterhuis, D.M., D. Loka, E.M. Kawakami, W.T. Pettigrew. 2014. The physiology of potassium in crop production. Adv. Agron. 126:203-233.

Oyewole, O.S., I.O.J. Ajayi, R.I. Rotimi. 2012. Growth of cocoa (Theobroma cacao L.) seedling on old cocoa soils amended with organic and inorganic fertilizers. African J. Agric. Res. 7:3604-3608.

Purwanto, O.D., Sudradjat, Supijatno. 2017. Determination of nitrogen fertilizer requirement for four-year-old oil palm. Asian J. Appl. Sci. 5:1108-1115.

[Puslitbangbun] Pusat Penelitian dan Pengembangan Perkebunan. 2007. Cengkih: Budidaya Pendukung Tipe Unggul. Publ. Puslitbangbun, Bogor, ID.

Ries, S.K., R. Houtz. 1983. Triacontanol as growth regulator. HortScience. 18:654-662.

Ries, S.K. 1985. Regulation of plant growth with triacontanol. Crit. Rev. Plant Sci. 2:239-285.

Scotti, R., P. Conte, A.E. Berns, G. Alonzo, M.A. Rao. 2013. Effect of organic amandements on the evolution of soil organic matter in soils stressed by intensive agricultural practices. Cur. Organic. Chem. 17:29983005 .

Setiawan, R. Rosman. 2015. Status penelitian, penerapan teknologi dan strategi pengembangan tanaman cengkeh berbasis ekologi. Perspektif 14:27-36.

Sharma, M.K., N.K. Joolka. 2000. Influence of triacontanol and paclobutrazol on the drought tolerance of nonpareil almond. Indian J. Hort. 57:118-121.
Sharma, M.K., N.K. Joolka. 2011. Influence of triacontanol and paclobutrazol on growth and leaf nutrient status of nonpareil almond under different soil moisture regimes. Indian J. Hort. 68:180-183.

Shintarika, F., Sudradjat, Supijatno. 2015. Optimasi dosis pupuk nitrogen dan fosfor pada tanaman kelapa sawit (Elaeis guineensis Jacq.) belum menghasilkan umur satu tahun. J. Agron. Indonesia 43:250-256.

Sitinjak, R.R., D. Pandiangan. 2014. The effect of plant growth regulator triacontanol to the growth of cacao seedlings (Theobroma cacao L.). Agrivita 36:260267.

Sudarsono,W.A.,M.Melati,A.A.Sandra.2013.Pertumbuhan, serapan hara dan hasil kedelai organik melalui aplikasi pupuk kandang sapi. J. Agron. Indonesia 41:202-208.

Sudradjat, H. Saputra, S. Yahya. 2015. Optimization of NPK compound fertilizer package rate on one year old oil palm (Elaeis guineensis Jacq.) trees. International J. Sciences: Basic Appl. Res. 20:365-372.

Tantos, A., A. Meszaros, T. Farkas, J. Szalai. 2001. Triacontanol-supported micro-propagation of woody plants. Plant Cell Reports 20:16-21.

Triadiati, N.R. Mubarik, Y. Ramasita. 2013. Respon pertumbunan tanaman kedelai terhadap Bradyrhizobium japonicum toleran masam dan pemberian pupuk di tanah masam. J. Agron. Indonesia 41:24-31.

Tomar, C.S., N. Singh. 2007. Effect of foliar application of nutrients and bioregulators on growth, fruit set, yield and nut quality of walnut. Indian J. Hort. 64:271273.

Veras, M.L.M., J.S.D.M. Filho, L.D.S. Alves, T.H.D.S. Irineu, N.A. Sousa, L.F. de Figueiredo, E.N. de Melo, L.D.M. Cavalcante, T.J. Dias, A.C.G. Neto. 2016. Guava rootstocks growth under incorporation of cattle manure and application of organic fertilizer the base of fruit of peel. Afr J. Agric Res. 11:37773787 .

Wattimena, G.A. 1988. Zat Pengatur Tumbuh Tanaman. Publ. Pusat Antar Universitas (PAU). Institut Pertanian Bogor, Bogor, ID. 